\title{
EVALUATION OF TECHNICAL TEACHING EFFECTIVITY USING
} TRADITIONAL TECHNOLOGY

\section{Jana DEPEŠOVÁ - Anna TIRPÁKOVÁ}

Resumé: The aim of this article is to present the applications of nonparametric statistic methods, especially the Wilcoxonov test and $\chi^{2}-$ test, in evaluating pedagogic research projects.

Key words: pedagogical research, nonparametrical methods of mathematical statistics, $\chi^{2}-$ test, unpaired Wilcoxonov test, traditional technology.

\section{VYHODNOTENIE EFEKTÍVNOSTI VÝUČBY TECHNICKEJ VÝCHOVY PRI ZAČLENENÍ TRADIČNÝCH TECHNOLÓGIÍ}

Resumé: Na vybraných základných školách Slovenskej republiky bol realizovaný pedagogický výskum, ktorého cielom bolo dokázat' opodstatnenost' požiadavky začlenenia ludových remesiel do vyučovacieho procesu technickej výchovy na základnej škole. Ciel’om predloženého článku je prezentovat' vyhodnotenie výsledkov tohto výskumu pomocou neparametrických metód matematickej štatistiky a ich interpretácia.

Kl'účové slová: empirický pedagogický výskum, didaktický test, neparametrické testy, $\chi^{2}$ - test, dvojuýberový Wilcoxonov test, tradičné technológie.

Úvod

Vláda Slovenskej republiky svojím uznesením č. $628 \mathrm{z}$ roku 1995 reagovala na závery generálnej konferencie UNESCO a vytvorila administratívne podmienky na doplnenie učebných osnov základných škôl o tradičné remeselné techniky. Do učebných osnov pracovného vyučovania na 1 . stupni základných škôl a učebných osnov technickej výchovy na 2 . stupni základných škôl bol v rámci volitel'ného učiva, resp. alternatívneho učiva zapracovaný tematický celok „L'udové tradície a remeslá na Slovensku“ a tematický celok „Vybrané odbory techniky“. Do obsahu týchto tematických celkov sú zaradené tradičné technológie používané v l’udových remeslách daného regiónu, ako aj spracovanie tradičných materiálov. Predmetom nášho výskumu bolo zistit', či zaradenie týchto tematických celkov ovplyvní vedomostnú úroveň žiakov v predmete technická výchova a postoje žiakov k tomuto predmetu. Pri štatistickej analýze výsledkov výskumu boli okrem metód deskriptívnej štatistiky použité neparametrické testovacie metódy. Úroveň vedomostí sme testovali pomocou dvojvýberového Wilcoxonovho testu a postoje žiakov pomocou $\chi^{2}$ - testu. Výpočty sme realizovali pomocou programu STATISTICA.

\section{Charakteristika sledovaných súborov a použité metódy}

Ako prostriedok na hodnotenie vedomostnej úrovne žiakov sme použili didaktický test. Jeho konštrukciu sme konzultovali s učitel'mi technickej výchovy ako aj s metodikmi pre technickú výchovu. Formulácia použitých otázok v didaktickom teste bola vybraná zo Vzdelávacieho štandardu s exemplifikačnými úlohami z technickej výchovy pre 2. stupeň ZŠ. Na zistenie postojov žiakov k predmetu technická výchova a ich postojov $\mathrm{k}$ zaradeniu prvkov tradičných l'udových remesiel do vyučovania technickej výchovy sme použili dotazník.

Výskumnú vzorku tvorili žiaci 6. ročníka ZŠ. Do experimentálnej skupiny boli zaradení žiaci $\mathrm{z}$ tried s rozšíreným vyučovaním regionálnej výchovy a do kontrolnej skupiny žiaci $\mathrm{z}$ tried s klasickým vyučovaním technickej výchovy. Naším ciel'om bolo dokázat', že žiaci experimentálnej skupiny dosahujú vyššiu vedomostnú úroveň ako žiaci vyučovaní tradičným spôsobom.

Počet respondentov postojového dotazníka zaradených do experimentu:

- žiaci vyučovaní na školách s klasickým vyučovaním technickej výchovy - 166 ,

- žiaci vyučovaní na školách s rozšíreným vyučovaním regionálnej výchovy - 147. 
Počet respondentov vedomostného testu zaradených do experimentu:

- žiaci vyučovaní na školách s klasickým vyučovaním technickej výchovy - 190,

- žiaci vyučovaní na školách s rozšíreným vyučovaním regionálnej výchovy - 137.

Vyhodnotenie výsledkov výskumu pomocou neparametrických testov

Vedomostnú úroveň žiakov experimentálnej a kontrolnej skupiny sme porovnávali pomocou dvojvýberového Wilcoxonovho testu. Tento test patrí medzi najpoužívanejšie neparametrické metódy matematickej štatistiky. Používa sa ako neparametrická alternatíva parametrického t-testu pre dva nezávislé výberové súbory. Použitie parametrických metód je viazané na splnenie určitých predpokladov (predpoklad o normálnom rozdelení, predpoklad o rovnakej variabilite a d'alšie). Tieto predpoklady by mali byt' overené predtým, ako sa príslušný test použije. Ak neplatí niektorý z predpokladov použitia štatistickej metódy, príslušná štatistická metóda je použitá neoprávnene a závery, ktoré sú vyvodené pomocou tejto metódy z experimentálnych údajov, môžu byt' skreslené. Často sú k dispozícii údaje, pri ktorých nie je možné overit', či pre ne platia predpoklady pre použitie niektorej parametrickej metódy. V takýchto prípadoch je výhodné použit' niektorú z neparametrických metód, ktorých použitie predpokladá splnenie menej prísnych podmienok. Nakol'ko neparametrické metódy sú menej citlivé a presné ako metódy parametrické, platí pravidlo, že ak sú splnené predpoklady použitia parametrickej metódy, dávame prednost' parametrickej metóde pred metódou neparametrickou. Prehl'ad najpoužívanejších a neparametrických metód a tiež základné predpoklady ich použitia je možné nájst' napríklad v publikácií (CHAJDIAK RUBLÍKOVÁ - GUDÁBA, 1994).

Pozorovaným znakom je počet správnych odpovedí v didaktickom teste. Ked’že predpoklad o normálnom rozdelení početností správnych odpovedí v testoch nie je opodstatnený, na testovanie rozdielov vo vedomostnej úrovni žiakov experimentálnej a kontrolnej skupiny sme použili dvojvýberový Wilcoxonov test.

Test sme realizovali pomocou programu STATISTICA. Po zadaní vstupných údajov vo výstupnej zostave počítača dostaneme pre zvolený dvojvýberový Wilcoxonov test tieto výsledky: hodnotu testovacieho kritéria $z$ a hodnotu $p$, čo je pravdepodobnost' chyby, ktorej sa dopustíme, ked' zamietneme testovanú hypotézu. Ak je vypočítaná hodnota pravdepodobnosti $p$ dostatočne malá $(\mathrm{p}<0,05$ resp. $\mathrm{p}<0,01$ ), testovanú hypotézu $\mathrm{H}_{0}$ o rovnosti stredných úrovní pozorovaných znakov zamietame (na hladine významnosti 0,05 resp. 0,01). V opačnom prípade hypotézu $\mathrm{H}_{0}$ nemôžeme zamietnut', pozorované rozdiely nie sú štatisticky významné. Po zadaní výsledkov vedomostných testov sme dostali nasledujúce výsledky: $z=11,416 \quad p=0,00001$.

Ked’že hodnota $p$ je dostatočne malá, testovanú hypotézu $\mathrm{H}_{0}$ zamietame na hladine významnosti $0,01 \mathrm{v}$ prospech alternatívnej hypotézy. Tým sme dokázali, že žiaci experimentálnej skupiny dosahujú štatisticky významne lepšie výsledky ako žiaci kontrolnej skupiny. Pre názornejšie porovnanie výsledkov testov oboch skupín žiakov sme počty správnych odpovedí v každej otázke vyjadrili v percentách a znázornili graficky.

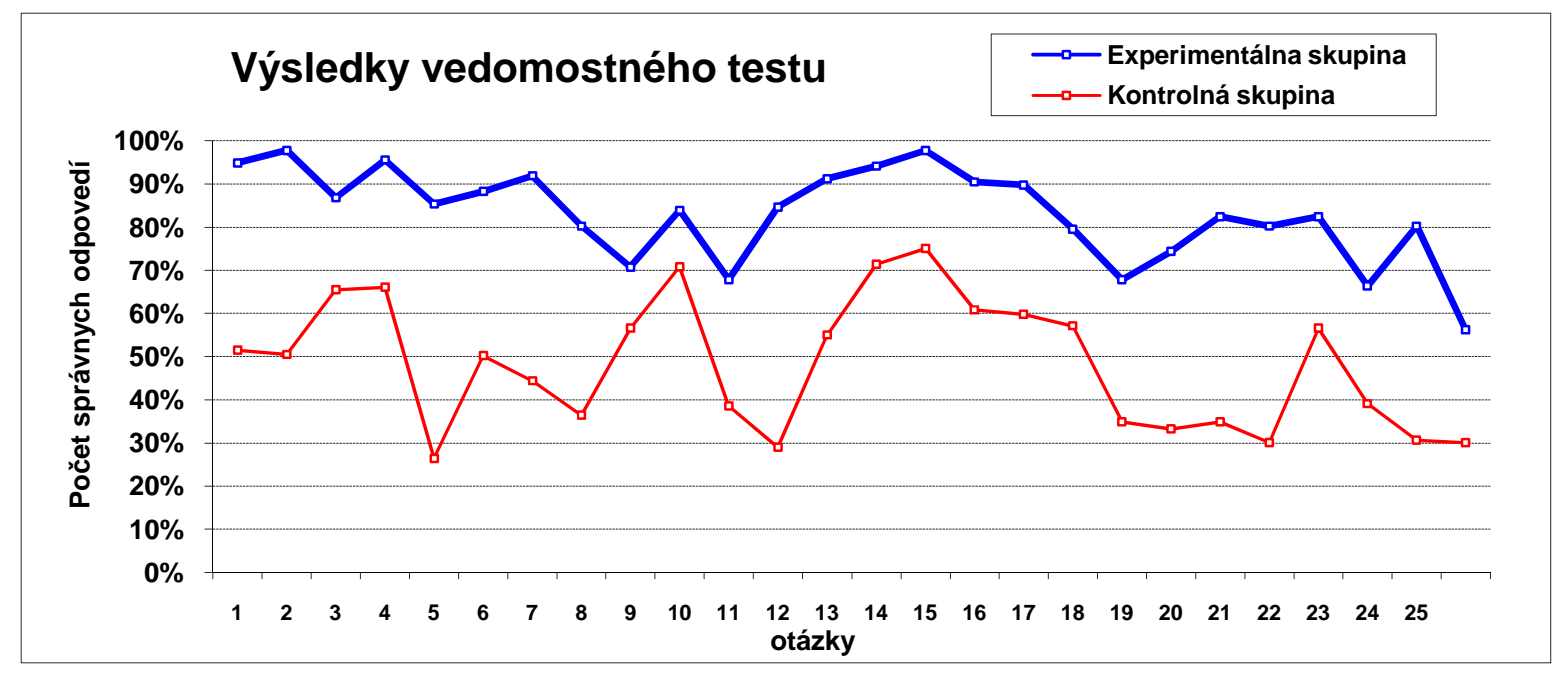


V d’alšej časti realizácie výskumu sme porovnávali postoje žiakov 6 . ročníka k predmetu Technická výchova. Na položky v dotazníku na zist'ovanie postojov k technickej výchove a k tradičným technológiám odpovedali skupiny žiakov zaradených do experimentu.

Pri zatvorených položkách sme použili na vyjadrenie miery postoja žiakov Likertove škály, ktoré obsahovali spravidla 5 alternatív odstupňovaných podl'a intenzity postoja. V jednej z položiek sme využili možnost' priradenia číselnej hodnoty jednotlivým ponúkaným alternatívam. Zaradením zatvorených položiek do dotazníka sme chceli využit' ich väčšiu jednoznačnost' merania v porovnaní s otvorenými a polootvorenými položkami a teda ich vyššiu reliabilitu. Pretože nevýhodou zatvorených položiek je ich povrchnost', v dotazníku sme zaradili aj položky otvorené. Ich výhodou je, že respondent môže odpovedat' vol'ne, nie je viazaný nanútenými odpoved’ami.

Tret'ou alternatívou, ktorú sme v dotazníku využili boli polootvorené položky. Tie umožňujú respondentovi zvolit' si alternatívu z uvedených možností odpovedí, ale ponúkajú aj možnost' pridat' alebo prejavit' svoj názor vo vol'nom riadku, ktorý je v položke zaradený.

Kombináciou uvedených typov položiek dotazníka sme chceli zvýšit' celkovú reliabilitu dotazníka.

Experimentálnu skupinu tvorili žiaci vyučovaní s dôrazom na l'udové tradície a kontrolnú skupinu tvorili žiaci vyučovaní klasickým spôsobom vyučovania technickej výchovy. Naším ciel’om bolo dokázat', že žiaci experimentálnej skupiny majú lepší postoj k predmetu Technická výchova ako žiaci vyučovaní tradične. Pozorovanými štatistickými znakmi sú znaky $\mathrm{X}, \mathrm{Y}$, pričom znakom $\mathrm{X}$ sme označili príslušnost' $k$ skupine a znakom $Y$ odpovede na položky v dotazníku. Testovanou hypotézou bude nulová hypotéza o nezávislosti pozorovaných znakov X, Y. Nulovú hypotézu budeme testovat' oproti alternatívnej hypotéze $\mathrm{H}_{1}$ : závislost' medzi pozorovanými znakmi je štatisticky významná. Ked’že pozorované znaky sú nominálne, nulovú hypotézu budeme testovat' pomocou $\chi^{2}$ - testu nezávislosti. Samotné výpočty sme realizovali na počítači pomocou programu STATISTICA. Po zadaní vstupných údajov dostaneme výstupnú zostavu počítača, v ktorej je uvedená kontingenčná tabul'ka, hodnota testovacieho kritéria $\chi^{2}$ a hodnota pravdepodobnosti $p$. Ak je vypočítaná hodnota pravdepodobnosti $p$ dostatočne malá ( $p<0,05$ resp. $p<0,01)$ testovanú hypotézu o nezávislosti pozorovaných znakov zamietame (na hladine významnosti 0,05 resp. 0,01 ). Po zadaní údajov získaných pomocou dotazníka sme dostali nasledujúce výsledky: $\chi^{2}=29,3242$ a pravdepodobnost' $p=0,000007$. To znamená, že na hladine významnosti 0,01 zamietame nulovú hypotézu v prospech alternatívnej hypotézy. Test potvrdil, že žiaci experimentálnej skupiny majú štatisticky významne odlišný názor na predmet Technická výchova. Z jednotlivých odpovedí je zrejmé, že žiaci experimentálnej skupiny hodnotia priebeh vyučovacieho procesu technickej výchovy pozitívnejšie ako žiaci vyučovaní tradičným spôsobom.

\section{Záver}

Výsledky pedagogického výskumu potvrdili, že zaradenie prvkov tradičných l'udových remesiel do vyučovacieho procesu technickej výchovy pozitívne ovplyvňuje vedomostnú úroveň žiakov v skúmanom vyučovacom predmete. Žiaci, ktorí boli vyučovaní na školách zaradených do projektu škôl s rozšíreným vyučovaním regionálnej výchovy, majú lepší postoj $\mathrm{k}$ technickej výchove v porovnaní so žiakmi vyučovanými na školách s klasickým vyučovaním technickej výchovy. Zaradenie l'udových remesiel a tradičných l'udových technológií pozitívne ovplyvňuje osobnú a národnú identitu žiakov a rozvíja u žiakov ich tvorivé schopnosti. Žiaci tým načerpajú množstvo informácií a vedomostí nielen z oblasti technickej výchovy, ale naplní sa aj spoločenská požiadavka oživovania, zachovávania a poznávania l’udových tradícií.

Analýza zachovávania tradičných l'udových remesiel na Slovensku, porovnanie zachovávania tradícií v niektorých krajinách Európskej únie, ako aj realizácia projektov rozšírenej regionálnej výchovy na niektorých základných školách, je podnetom k celospoločenskému riešeniu problematiky zachovávania tradičných remesiel, ale aj podnetom k zvyšovaniu efektívnosti technickej výchovy. Riešená problematika je podporovaná aj mnohými slovenskými a medzinárodnými dokumentmi.

Výsledky uskutočneného výskumu po zaradení do edukácie môžu pozitívne ovplyvnit' priebeh vyučovacieho procesu technickej výchovy, ale môžu byt' aj súčast'ou systému celoživotného technického vzdelávania v rámci štruktúry: predškolské zariadenia, základná škola, mimoškolské zariadenia, vzdelávanie na 
stredných školách, vysoké školstvo a univerzita tretieho veku.

Výsledky výskumu tradičných remeselných technológií doplnené vhodnými metodickými materiálmi, môžu prispiet' k obohateniu vzdelávania technickej výchovy na rôznych typoch škôl, resp. ponúkajú možnost' využitia v rámci vytvorenia centier tradičných rómskych remesiel pod záštitou rezortu školstva, rómskych politických, resp. iných organizácií.

\section{Literatúra}

1. CHAJDIAK, J.- RUBLIKOVÁ, E.GUDÁBA, M.: Štatistické metódy $v$ praxi, STATIS, Bratislava, 1994, ISBN 80-85659-02-6. 2. VRÁBELOVÁ, M. - MARKECHOVÁ, D.: Pravdepodobnost' a štatistika, Fakulta prírodných vied UKF v Nitre, 2001, ISBN 80-8050-429-6.

3. CLAUSS, G. - EBNER, H.: Základy štatistiky pre psychológov, pedagógov a sociológov, SPN, Bratislava, 1988.

4. SENČEK, F. - BAJCSY, J.: Pravdepodobnostné charakteristiky testov. Technológia vzdelávania, č. 3, 1994. s. 11 - 13. ISSN 1335-003X.

5. VARGOVÁ, M. - DEPEŠOVÁ, J.: Štúdium odboru učitel'stva pre 1. stupeň základnej školy so zameraním na vyučovanie technických predmetov. In: Zborník Príprava učitelov elementaristov a európsky multifunkčný priestor. Prešov: PU PF, 2005. s. 556 - 561. ISBN 808068-372-7.
6. TOMKOVÁ, V.: Rozvíjanie klúčcoých kompetencií žiakov základných škôl pomocou tvorivých úloh v technickej výchove. In: TECHNIKA - INFORMATIKA - EDUKACJA. TOM VII. Sandomierzu: Diecezjalne i Drukarnia w Sandomierzu, 2007, s. 105-109. ISBN 978-83 88845-90-1.

7. DEPEŠOVÁ, J.: Ludové remeslá v zahraničí. In: Zborník Technické vzdelanie ako súčast' všeobecného vzdelania. B. Bystrica: FPV UMB, 2005. s. 89 - 92. ISBN 80-80-83-151-3.

8. DEPEŠOVÁ, J.: Vplyv začlenenia prvkov tradičných technológií na rozvoj motorických zručností a vedomostí žiakov $v$ technickej výchove. In Zborník Multikultúrne aspekty edukácie v učiacej sa spoločnosti. Žilina: ŽU, 2007. s. 29 - 33. ISBN 978-80-89284-06-1.

PaedDr. Jana Depešová, PhD.,

Katedra techniky a informačných technológií, Univerzita Konštantína Filozofa, Dražovská $\begin{array}{lllll}\text { cesta } 4, & 949 & 01 & \text { Nitra, } & \text { E-mail: }\end{array}$ jdepesova@ukf.sk

doc. RNDr. Anna Tirpáková, CSc., Katedra matematiky, Univerzita Konštantína Filozofa, Trieda A. Hlinku 1, 94901 Nitra, Email: atirpakova@ukf.sk 